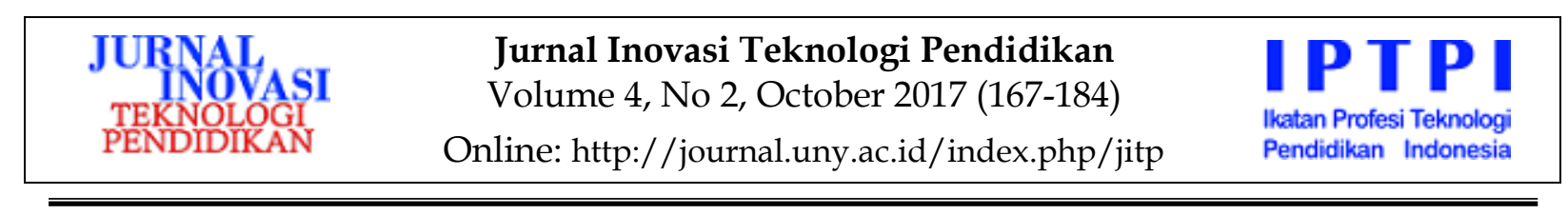

\title{
PENGEMBANGAN GAME EDUKASI BERBASIS ANDROID TENTANG DOMAIN TEKNOLOGI PENDIDIKAN
}

\author{
Ujang Nendra Pratama, Haryanto \\ Program Studi Teknologi Pembelajaran PPs UNY, Universitas Negeri Yogyakarta \\ uujgagak@gmail.com, haryan62@yahoo.co.id
}

\begin{abstract}
Abstrak
Penelitian ini bertujuan untuk menghasilkan produk game Android berisi materi Domain TP yang layak sebagai alternatif media belajar bagi mahasiswa prodi TP FIP UNY. Nilai kelayakan diketahui melalui penilaian ahli, calon pengguna, dan daya guna pembelajaran. Pengembangan produk dilaksanakan melalui lima tahap utama: studi pendahuluan, perencanaan, perancangan, pengembangan, dan evaluasi. Pengumpulan data dilakukan dengan wawancara studi pendahuluan, identifikasi gaya belajar, validasi ahli, validasi calon pengguna, serta pengujian eksperimen. Jumlah responden terdiri dari satu dosen pengampu, dua ahli media dan materi, serta 60 mahasiswa. Hasil penelitian menunjukkan bahwa produk yang dikembangkan telah memenuhi kriteria kelayakan dari validasi media, materi, calon pengguna, serta uji daya guna. Penilaian ahli materi masuk dalam kategori sangat layak, sedangkan ahli media dan calon pengguna masuk dalam kategori layak. Produk juga terbukti memiliki kelayakan daya guna berdasarkan perbedaan rerata nilai pretes dan postes kedua kelompok uji, sehingga perbandingan nilai gain menunjukkan perbedaan yang signifikan.
\end{abstract}

Kata kunci: game edukasi, domain TP, Android

\section{THE DEVELOPING ANDROID-BASED EDUCATIONAL GAME ON EDUCATIONAL TECHNOLOGY DOMAINS}

\author{
Ujang Nendra Pratama, Haryanto
}

Program Studi Teknologi Pembelajaran PPs UNY, Universitas Negeri Yogyakarta uujgagak@gmail.com, haryan62@yahoo.co.id

\begin{abstract}
The study aims to produce an Android game on EduTech Domain materials which appropriate as an alternative learning media for students of Educational Technology in FIP UNY. Appropriateness was known through assessment of experts, future users, and learning usability. The product development procedure implemented through five main stages: preliminary study, planning, design, development, and evaluation. Data collection was done by preliminary study interview, learning style identification, expert validation, future users validation, and experimental testing. The participants consisted of a supporting lecturer, two experts of media and subject matter, seven students, and also 60 students. The result showed that the developed product has been able to reach appropriateness criterion from the validations of media, subject matter, future users, and usability testing. Subject matter experts assessment included in the very appropriate category, while media experts and future users included in the appropriate category. The product are also had usability appropriateness evidently based on differences between the mean values of pre-test and post-test of both test group, so that the comparison of gain value showed a significant differences.
\end{abstract}

Keywords: educational game, EduTech domains, Android 


\section{Pendahuluan}

Teknologi Pendidikan berperan utama sebagai disiplin ilmu yang memfasilitasi pembelajaran agar terjadi secara efektif dan efisien. Association for Educational Communications and Technology (AECT) telah mengkaji dan mengembangkan definisi Teknologi Pendidikan seiring perkembangan paradigma belajar dan kemajuan teknologi itu sendiri. Teknologi Pendidikan telah berkembang dari anggapan sebagai keterampilan menjadi profesi dan bidang kajian (Seels \& Richey, 1994, p. 117). Saat ini bidang Teknologi Pendidikan telah memiliki wilayah garapan dan profesi, serta beracuan teori dan praktik secara jelas. Disamping itu, tujuan bidang juga meluas pada peningkatan kinerja profesional, sehingga tidak hanya terbatas pada masalah pembelajaran di lembaga pendidikan. Teknologi Pendidikan dapat beroperasi dimana belajar itu diperlukan, baik oleh perorangan, kelompok, maupun organisasi (Miarso, 2013, p. 700).

Tahun 2015, prodi Teknologi Pendidikan FIP UNY memiliki visi sebagai pusat pengembang dan pembaru Teknologi Pendidikan yang mandiri dan berwawasan Nasionalisme-Religius pada 2025. Profil lulusan diharapkan memiliki kompetensi utama sebagai (1) Tenaga Kependidikan, (2) Pendidik, dan (3) Wirausaha di bidang Teknologi Pendidikan. Sebagai upaya perwujudannya, dalam kurikulum prodi TP FIP UNY terdapat mata kuliah wajib dan konsentrasi terkait capaian kompetensi tujuan tersebut. Dasar-dasar Teknologi Pendidikan merupakan mata kuliah wajib yang diberlakukan untuk prodi TP di semester 1 (4 SKS teori). Mata kuliah ini mewajibkan mahasiswa untuk memahami landasan dan wawasan keilmuan Teknologi Pendidikan. Dalam mata kuliah ini terdapat topik materi tentang definisi dan kawasan TP meliputi bahasan (1) definisi $\mathrm{TP}$, (2) kawasan TP, (3) sumber-sumber yang mempengaruhi TP, (4) praktik TP, serta (5) implikasi definisi TP.
Kawasan TP terurai dari komponen definisi yang didasari oleh asumsi untuk menyempurnakan wilayah kegiatan ilmuwan dan praktisi. Seels dan Richey melalui AECT 1994 mendefinisikan Teknologi Pembelajaran sebagai "teori dan praktik dalam desain, pengembangan, pemanfaatan, pengelolaan, serta evaluasi proses dan sumber untuk belajar "(Seels \& Richey, 1994, p. 1). Berdasarkan definisi tersebut, maka terdapat lima kawasan sebagai aspek perhatian untuk kajian dan bidang garapan, yaitu desain, pengembangan, pemanfaatan, pengelolaan, dan evaluasi.

Istilah-istilah tersebut berasal dari dasar pengetahuan dan tugas yang dilakukan setiap profesional di bidangnya. Setiap fungsi istilah memiliki lingkup dan ciri khas untuk berkembang menjadi bidang studi sendiri (Seels \& Richey, 1994, p. 12). Dalam masing-masing kawasan terdapat empat subkategori utama sebagai lingkup kegiatan atau satuan tugas (Seels \& Richey, 1994, p. 30). Berikut diuraikan secara singkat kelima kawasan TP 1994 beserta cakupannya.

Kawasan desain berasal dari dasar psikologi pembelajaran yang dilengkapi pendekatan teori sistem dalam pembelajaran. Perpaduan ini menciptakan suatu metodologi (Seels \& Richey, 1994, p. 31). Desain pada kawasan TP diartikan sebagai "proses untuk menentukan kondisi belajar". Tujuan desain adalah menciptakan strategi dan produk pada tingkat makro (program dan kurikulum) dan juga mikro (bahan pelajaran dan modul). Definisi desain mengacu pada penentuan spesifikasi (Seels \& Richey, 1994, p. 32). Kawasan desain meliputi empat cakupan utama, yaitu (1) desain sistem pembelajaran; (2) desain pesan; (3) strategi pembelajaran; dan (4) karakteristik pebelajar.

Kawasan pengembangan lahir dari produksi media. Pengembangan diartikan sebagai "proses penerjemahan spesifikasi desain ke dalam bentuk fisik." Kawasan pengembangan tersebut meliputi berbagai variasi teknologi yang digunakan (Seels \& Richey, 1994, p. 38). Kawasan pengembangan mencakup fungsi desain, produksi, 
dan penyampaian (Seels \& Richey, 1994, p. 39). Kawasan ini meliputi (1) teknologi cetak, (2) teknologi audiovisual, (3) teknologi komputer, dan (4) teknologi terpadu.

Kawasan pemanfaatan menuntut adanya penggunaan, deseminasi, difusi, implementasi, dan pelembagaan yang sistematis. Hal-hal tersebut sering bersentuhan langsung dengan kebijakan dan regulasi. Pemanfaatan diartikan sebagai "aktivitas menggunakan proses dan sumber untuk belajar." Kawasan pemanfaatan meliputi (1) pemanfaatan media, (2) difusi inovasi, (3) implementasi dan pelembagaan, serta (4) kebijakan dan regulasi.

Kawasan pengelolaan merupakan bagian integral bidang Teknologi Pendidikan dan dari peran kebanyakan profesi TP. Teori manajemen umum mulai diterapkan dan diadopsi karena semakin rumitnya praktik pengelolaan bidang TP. Manajemen adalah keterampilan dasar yang meliputi organisasi program, supervisi personel, perencanaan, administrasi dana dan fasilitas, serta pelaksanaan perubahan (Seels \& Richey, 1994, pp. 52-53). Kawasan ini meliputi (1) manajemen proyek, (2) manajemen sumber, (3) manajemen sistem penyampaian, dan (4) manajemen informasi.

Kawasan evaluasi cenderung untuk penilaian pembelajaran formal yang lebih sistematik dan ilmiah. Kawasan evaluasi tumbuh bersama perkembangan bidang penelitian dan metodologi (Seels \& Richey, 1994, p. 58). Evaluasi diartikan sebagai "proses penentuan memadai tidaknya pembelajaran dan belajar." Kunci konsep evaluasi adalah penentuan nilai. Evaluasi berlaku untuk program, proyek, dan produk pembelajaran. Kawasan ini mencakup (1) analisis masalah, (2) pengukuran acuan patokan, (3) penilaian formatif, dan (4) penilaian sumatif.

Kawasan TP 1994 secara tidak langsung mengandung makna sebagai langkahlangkah sistematik pengembangan pembelajaran. (Seels \& Richey, 1994, p. 8). Kawasan TP 1994 merupakan wilayah yang menjadi landasan pengetahuan dan fungsi praktisi dengan demikian diklasifikasikan sesuai kawasan yang bersangkutan (Seels \& Richey, 1994, p. 118). Kawasan tersebut juga berfungsi sebagai taksonomi klasifikasi berlandaskan hubungan (Seels \& Richey, 1994, p. 25). Hubungan antarkawasan tidak bersifat linier namun saling melengkapi dan bersifat sinergistik (Seels \& Richey, 1994, p. 27).

Setiap kawasan memberikan sumbangan teori dan praktik yang menjadi landasan untuk profesi (Seels \& Richey, 1994, p. 10). Dalam bidang TP, pendekatan dan perancangan model pembelajaran ditujukan untuk berbagai tingkat konsentrasi, mulai dari satuan aktivitas, unit, pelajaran, modul, kursus, kurikulum, program, institusional, dan sampai pada tingkat nasional serta global (Spector, 2012, p. 22). Spector (2012, pp. 162-169) merangkum beberapa prinsip dan contoh penerapan TP pada berbagai konteks kerja, seperti di pendidikan dasar dan menengah (K-12 education), pendidikan tinggi, bisnis dan industri, lembaga pemerintahan, serta organisasi non profit atau non pemerintahan.

Definisi TP 1994 mengenal dengan baik tradisi bidang yang sedang berlaku serta kecenderungannya di masa depan. Definisi TP 1994 dapat dianggap sebagai kerangka untuk mengakomodasikan perkembangan praktik TP di masa depan (Seels \& Richey, 1994, p.123). Berdasarkan Permenpan Nomor PER/2/M.PAN/3/2009 tentang Jabatan Fungsional Pengembang Teknologi Pembelajaran dan Angka Kreditnya (Kementerian Pendayagunaan Aparatur Negara republik Indonesia, 2009), dinyatakan bahwa tugas pokok Jabatan Pengembang TP di lingkungan PNS adalah melaksanakan (1) analisis dan pengkajian sistem/model teknologi pembelajaran, (2) perancangan sistem/model teknologi pembelajaran, (3) produksi media pembelajaran, (4) penerapan sistem/model dan pemanfaatan media pembelajaran, (5) pengendalian sistem/model pembelajaran, dan (6) evaluasi penerapan sistem/model dan pemanfaatan media pembelajaran.

Teknologi Pendidikan saat ini telah berkembang sebagai disiplin ilmu dan pro- 
fesi dengan kajian yang disempurnakan melalui definisi 2004. Selain itu, profesi dan praktik TP juga semakin berkembang seiring bertambahnya lingkungan kerja bidang TIK. Namun Permenpan nomor PER/2/M.PAN/3/2009 membuktikan bahwa kelima domain TP 1994 tetap tidak bisa dilepaskan sebagai wilayah bidang garapan yang utama.

Batasan konseptual Teknologi Pendidikan dapat ditetapkan melalui struktur yang disarankan oleh kawasan tersebut, sebab kelimanya mencerminkan wilayah praktik dan spesialisasi utama (Seels \& Richey, 1994, p. 127). Kawasan TP memiliki urgensi untuk dipahami secara konseptual oleh mahasiswa prodi TP, karena guna memenuhi kualifikasi dalam pekerjaan dan jabatannya kelak, seorang teknolog pendidikan harus menguasai satu atau lebih kawasan bidang TP (Seels \& Richey, 1994, p. 111).

Tetapi harus diakui bahwa bidang dan profesi TP di Indonesia saat ini belum optimal, baik dalam hal desain, pengembangan, pemanfaatan, pengelolaan, maupun evaluasinya (Warsita, 2013, p. 78). Teknologi pendidikan hanya mungkin dikembangkan dan dimanfaatkan apabila ada profesi pengembang TP yang terampil, mahir, dan atau ahli dalam melaksanakan perancangan, pengembangan, pemanfaatan, penilaian, serta pengelolaan proses dan sumber untuk belajar (Miarso, 2013, p. 56).

Sebagai bidang yang memiliki perhatian khusus sebagai ilmu terapan, Teknologi Pendidikan perlu meningkatkan kualitas para profesionalnya. Karena tersedianya tenaga secara terus-menerus, dengan jumlah dan mutu yang meningkat, merupakan kunci keberhasilan strategi penerapan Teknologi Pendidikan (Miarso, 2013, p. 13). Oleh karena itu, diperlukan penguatan kembali untuk para akademisi, peneliti, dan praktisi. Salah satu upaya yang dapat dilakukan dari kalangan akademisi adalah memberikan penguatan kembali pada mahasiswa prodi $\mathrm{TP}$, agar para calon profesional tersebut nantinya dapat menjadi peneliti dan praktisi yang mampu membenahi permasalahan TP yang ada.
Materi tentang Domain TP perlu dikuasai secara cepat dan menyeluruh oleh setiap mahasiswa TP FIP UNY. Namun, berdasarkan diskusi dengan dosen pengampu mata kuliah Dasar-dasar TP, diketahui bahwa saat bahasan materi telah ditinggalkan, masih terdapat banyak pertanyaan mengenai penjelasan ulang dan keterkaitan materi baru dengan kawasan TP oleh mahasiswa. Lebih lanjut, media dan sumber belajar kurang bervariasi dan kurang membelajarkan dalam arti yang sebenarnya.

Kemudian, berdasarkan wawancara dengan perwakilan mahasiswa TP FIP UNY angkatan 2015, mahasiswa menceritakan kesulitan belajar karena terbatasnya waktu pembahasan di perkuliahan. Pembahasan definisi dan kawasan TP hanya berlangsung tiga pertemuan. Hal ini menyebabkan tidak tersampaikannya seluruh sasaran pembelajaran secara rinci karena materi juga sangat luas. Para mahasiswa mengalami kesulitan dan kebingungan ketika menjelaskan konseptual, contoh praktik, dan profesi terkait kawasan TP. Hasil wawancara ini diperkuat dengan diskusi para mahasiswa sebelumnya melalui percakapan grup WhatsApp.

Pembelajaran Domain TP masih cenderung dengan instruksi konvensional. Para mahasiswa menyatakan bahwa sumber belajar yang tersedia hanya dari buku dan pertemuan kelas, sehingga dinilai belum memadai. Media buku hanya memberikan penyampaian materi statis tanpa ilustrasi langsung dan pertemuan kelas hanya dapat dilaksanakan dengan waktu terbatas. Menurut dosen pengampu, materi Domain TP akan terbantu jika ada media praktis yang dapat menjelaskan konsepkonsep secara ringkas dan terilustrasi. Selain itu, media perlu berbentuk mobile learning yang dapat digunakan dimanapun dan kapanpun. Para mahasiswa juga sepakat apabila ada alternatif media belajar baru berbentuk aplikasi mobile, karena seluruh mahasiswa TP angkatan 2015 telah memiliki ponsel cerdas dan sebagian besar berbasis Android. Pengembangan media bel- 
ajar untuk generasi digital saat ini perlu memperhatikan tren teknologi serta budaya konsumsi yang sedang berjalan dan berkembang.

Materi domain TP merupakan pengetahuan yang lebih bersifat konseptual. Konsep merupakan pengelompokan melalui karakteristik umum yang dibedakan dari hal-hal lain yang tidak sama karakteristiknya (Alessi \& Trollip, 2001, p. 121). Konsep pembelajaran adalah pembentukan representasi untuk mengenali sifat, menyesuaikannya ke dalam contoh baru, dan memisahkan contoh dari yang bukan contoh (Schunk, 2012, p. 408). Kelima Domain TP 1994 dapat dipelajari sebagai suatu konsep karena menunjukkan keragaman terpadu yang membentuk kesatuan kompleks. Informasi konseptual menuntut agar tidak sekedar diketahui semata, tapi juga agar dimengerti sampai pada implikasi penuh, sehingga ranah belajar kognitif yang dituju harus sampai tingkat pemahaman. Pemahaman adalah langkah awal untuk dapat menjelaskan dan menguraikan sebuah konsep atau pengertian (Rusman, 2014, p. 171).

Belajar untuk pemahaman konsep dapat dilakukan dengan model pranata lanjutan (organsisasi pengantar), karena informasi yang diorganisasikan cenderung membuatnya mudah diingat dan ditarik kembali meskipun tanpa praktik (Alessi \& Trollip, 2001, p. 23). Teknik tersebut sesuai untuk pembelajaran materi Domain TP, karena Domain TP merupakan taksonomi klasifikasi yang berlandaskan hubungan, satu kesatuan yang kompleks, serta memiliki lingkup dan ciri khas untuk berkembang menjadi bidang sendiri. Tema utama pembelajaran dapat dikembangkan berdasarkan dimensi praktik, mengingat bahwa Teknologi Pendidikan selaku bidang terapan menuntut adanya kualitas praktik melalui keterampilan dan keahlian para praktisi sebagai profesional di bidangnya (Seels \& Richey, 1994, p. 104).

Profesi TP merupakan elemen pendukung utama dari tema, dimana pembahasan materi akan menguraikan keahlian para alumni prodi TP yang sudah bekerja sebagai teknolog pendidikan profesional. Kondisi dan nuansa dapat merujuk pada jabatan, profesi, dan instansi yang sesuai keadaan nyata di Indonesia. Lebih lanjut, untuk memfasilitasi ketuntasan pembelajaran dibutuhkan penilaian di setiap tahapan prosesnya. Menilai tujuan belajar kognitif dapat dilakukan dengan tes objektif berbentuk tes benar-salah (Rusman, 2014, p. 183). Tes tersebut dapat mewakili pokok bahasan yang lebih luas serta sesuai untuk mengukur fakta dan hasil belajar langsung (Widoyoko, 2013, pp. 51-53).

Ditinjau dari karakteristik media pembelajaran Domain TP, aplikasi mobile berbasis ponsel cerdas dapat dikembangkan dengan mengadopsi (1) model organisasi pengantar, (2) tema dimensi praktik relevan, (3) fantasi karakter profesi TP yang relevan, serta (4) penilaian atau kuis dengan tipe benar-salah.

Ponsel cerdas (smartphone) adalah perangkat yang digemari oleh masyarakat di berbagai daerah saat ini. Ponsel cerdas merupakan perangkat gerak yang memiliki kecanggihan lebih dari ponsel biasa. Ponsel cerdas memuat sistem operasi seperti halnya perangkat komputer lainnya. Beberapa sistem operasi yang digunakan pada ponsel cerdas diantaranya seperti Android, Blackberry, IOs, Windows phone, dll. Dari kesemuanya, Android adalah yang paling banyak digunakan. Android populer juga karena dipakai beberapa produsen internasional seperti Samsung, Lenovo, HTC, dan Sony. Produsen lokal seperti Mito, Evercross, Advan, dan Smartfren juga turut memanfaatkannya.

Android telah memimpin pasar ponsel cerdas dengan perbandingan jumlah pengguna yang tinggi. Data yang dilansir International Data Corporation (2016) menunjukkan bahwa Global Smartphone OS marketstore pada tahun 2012 sampai 2015 dikuasai Android dengan persentase 79,2\%, Apple/IOs 13,8\%, WindowsPhone 2,9\%, Blackberry 2,1\%, dan sistem operasi lain 2,1\%. Lebih dari 30 juta perangkat Android telah dimanfaatkan oleh pengguna ponsel cerdas, Android secara pasti menjadi tek- 
nologi ponsel perdas yang selangkah lebih maju (Finnegan, 2013, p. 10).

Perkembangan pemanfaatan dan ketergantungan smartphone saat ini telah mempengaruhi efisiensi waktu yang digunakan. Kebanyakan pengguna juga menggunakannya untuk memainkan game. Tetapi pengaruh edukatif dari game yang dimainkan perlu dipertanyakan, game yang dipasarkan melalui Android market (Playstore) berjumlah ribuan sampai saat ini (free $\mathcal{E}$ paid) dan belum tentu memiliki konsep edukatif yang jelas.

Telah terungkap bahwa 90\% dari game digital yang beredar di pasar ternyata memuat unsur dan tindakan kekerasan (Gunawardhana \& Palaniappan, 2015, p. 1730). Patut diduga jika beberapa game tersebut justru dapat menjadi alat pembodohan publik. Peraturan lunak pihak akuisisi Android (Google) membuat setiap programmer dan game developer dapat memasarkan produknya secara mudah. Penggunaan dari game tidak dilarang, tetapi harus dikendalikan dan diseleksi oleh pengguna agar game tersebut berkualitas sebagai mesin edukator.

Pada tingkatan yang luas, psikologi perkembangan dipengaruhi oleh situasi lingkungan, harus diakui bahwa game digital telah menjadi aspek yang tidak terpisahkan dari kehidupan anak-anak dan remaja saat ini (Blumberg \& Fisch, 2013, p. 2). Melaju dari tahun 2010, ponsel cerdas telah menjadi bentuk baru era mobile gaming. Game-game ponsel cerdas telah mampu bersaing dengan perangkat game konsol genggam seperti Nintendo DS dan Playstation portabel (Zechner, 2011, pp. 1-2).

Game ponsel cerdas Android yang dikembangkan sebagai game edukasi digital dapat memuat fitur-fitur yang berpotensi memberikan pengalaman permainan dan pembelajaran secara menarik dan berkelanjutan. Blumberg \& Fisch (2013, pp. 23) meringkas beberapa fitur tersebut, diantaranya (1) membuat penasaran (curiosity), (2) adanya tantangan (challenge), (3) menyertakan khayalan (fantasy), (5) adanya timbal balik (interactivity), (6) adanya ken- dali pengarahan (agency or control), (7) adanya keterkaitan karakter dan pemain (identity), (8) adanya umpan balik dari aktivitas (feedback), serta (9) adanya keterlibatan pribadi (immersion). Sehingga fitur-fitur tersebut sesuai pada paradigma belajar abad 21 .

Desain strategi pemanfaatan game edukasi biasa dilakukan dengan dua cara, yaitu memainkan game dalam pengaturan pembelajaran atau belajar langsung melalui game (Filsecker \& Kerres, 2014, pp. 463464). Game edukasi merupakan bentuk permainan yang dirancang untuk membantu pebelajar mencapai tujuan pembelajaran tertentu dan sekaligus memberikan motivasi (Clark \& Mayer, 2011, p. 367).

Pemanfaatan game dapat membantu desain perumpamaan atau desain permainan pada pembelajaran (Darmawan, 2015, p. 192). Game dapat dikategorikan sebagai salah satu format sajian multimedia pembelajaran. Ditinjau dari model game secara khusus, Ulicsak \& Williamson (2011, pp. 63-65) memberikan kategori secara rinci menjadi 20 jenis. Contoh diantaranya (1) platform games (2) sports games, (3) serious games, (4) casual games, (5) edutainment (educational games), (6) RPG (role playing games), dst. Jenis game edukasi sebenarnya lebih menekankan pada rancangan fungsional, bukan jenis pada rancangan teknis.

Untuk mengembangkan pembelajaran bermedia dibutuhkan penerapan prinsip-prinsip pembelajaran itu sendiri. Sehingga media yang dikembangkan dapat dikatakan sebagai aplikasi ilmiah. Pengembangan media belajar Domain TP berbentuk game Android ini memiliki dua landasan penekanan teori belajar, yaitu teori belajar behavioristik dan kognitivistik. Menurut behaviorisme, pembelajaran paling fundamental berasal dari pembentukan asosiasi-asosiasi antara stimulus dan respon yang memberikan manifestasi berbentuk perilaku (Schunk, 2012, p. 101). Sedangkan menurut kognitivisme, Bandura menyatakan bahwa manusia adalah organisme dinamis dalam mengolah informasi serta berperan sebagai makhluk sosial (Hergenhahn \& Olson, 2012, p. 383). 
Dari teori tersebut diuraikan prinsip-prinsip untuk aplikasi pembelajaran yang sesuai pada perancangan dan pengembangan produk. Bentuk-bentuk yang ditekankan dari penerapan prinsip-prinsip teori belajar behavioristik diantaranya (1) belajar dengan ketuntasan, (2) pembelajaran langsung (direct instruction) (Joyce, Weil, \& Calhoun, 2015, p. 341), (3) pemberian penguatan (reinforcement) yang tepat, (4) pembelajaran berbasis komputer (CBI), serta (5) pembelajaran terprogram (Skinner). Sedangkan bentuk-bentuk yang ditekankan dari penerapan prinsip-prinsip teori belajar kognitivistik diantaranya (1) pembelajaran resepsi bermakna (Ausubel), (2) prinsip pengorganisasian (Gestalt), (3) perangkat organisator pengantar ekspositoris, (4) modeling simbolis (Bandura), serta (5) pengolahan informasi visual (Wolfe).

Dalam mengembangkan produk game digital, dibutuhkan aplikasi pembangun (game engine) yang sesuai dengan tujuan serta memiliki performansi handal. Dalam penelitian ini, Unity adalah software yang terpilih. Unity merupakan aplikasi pembangun pertama yang ideal untuk mengembangkan kreasi game dengan berbagai fitur tinggi, serta memiliki kemampuan authoring beberapa platform yang berbeda. (Blackman, 2013, p. 11). Unity merupakan aplikasi pembangun game 3D yang memungkinkan pembuatan game bergaya 2D (Finnegan, 2013, p.196). Versi terakhir telah mendukung pengembangan untuk platform iOs, Android, Windows, Blackberry 10, OS $X$, Linux, peramban web, PlayStation, Xbox, serta Wii U (Sumpter, 2015, p. 1). Unity dan Android sangat berpotensi untuk dipadukan. Unity dapat menangani projek dan aset-aset game dengan baik. Selain itu, sofware tersebut merupakan salah satu teknologi representatif untuk aktivitas instruksional pengembangan game interaktif (Spector, 2012, p. 46).

Suatu pembelajaran dapat efektif jika menggunakan metode dan media pembelajaran yang sesuai gaya belajar pesertanya. Gaya belajar merupakan salah satu perepsi untuk analisis karakteristik pebel- ajar. Menurut Duckett \& Tatarkowski (2005, p. 11) gaya belajar adalah cara yang lebih disukai seorang individu dalam melakukan kegiatan belajar. Gaya belajar yang dipandang cukup berpengaruh terhadap keberhasilan media pembelajaran adalah tentang modalitas preferensi sensori visual, audio, dan kinestetik (VAK). Disamping itu, media pembelajaran game sesuai untuk menunjukkan kategori belajar yang melatih kecerdasan visual, kinestetik, dan atau auditif (Darmawan, 2015, p. 192).

Kecenderungan modalitas mahasiswa prodi TP FIP UNY secara umum pada angkatan 2002 sampai 2005 adalah campuran antara visual (10\%), auditorial (52\%), dan kinestetik (38\%), yang mana kecenderungan auditorial menempati porsi tertinggi (Muhtadi, 2006, p. 19). Dikarenakan kecenderungan tersebut telah ditemukan sekitar 10 tahun, maka perlu adanya penelitian kembali tentang gaya belajar VAK para mahasiswa TP FIP UNY meski terbatas pada satu lingkup angkatan yang dituju. Duckett \& Tatarkowski (2005, p. 14) telah memberikan instrumen terstandar untuk identifikasi gaya belajar VAK tersebut. Data dari survei gaya belajar yang lebih aktual dan dominan dapat dijadikan acuan empiris untuk merancang bentuk media belajar yang sesuai karakteristik mayoritas calon penggunanya.

Hasil belajar melalui game digital tergantung pada ketepatan rumusan pedagogis, mekanisme permainan, dan integrasi konten. (Ulicsak \& Wright, 2010, p. 5). Untuk menilai kualitas multimedia pembelajaran seperti game digital, diperlukan kriteria sebagai acuan terstandar. Alessi \& Trollip (2001, pp. 414-431) menguraikan beberapa aspek yang perlu dijadikan standar penilaian tersebut. Di antaranya (1) subjek materi, (2) informasi tambahan, (3) pertimbangan sikap, (4) tampilan antarmuka, (5) navigasi, (6) pedagogi (pembelajaran), (7) fitur tersembunyi, (8) robustness, dan (9) materi pendukung.

Susunan aspek-aspek tersebut dapat dikembangkan lebih lanjut menjadi kisikisi instrumen penilaian kelayakan multi- 
media pembelajaran oleh ahli bidang terkait. Masing-masing aspek dapat dikategorikan sesuai bidang ahli yang menilai. Ahli materi dapat meliputi aspek (1) subjek materi, (2) pembelajaran, (3) materi pendukung, dan (4) pertimbangan sikap. Sedangkan ahli media meliputi aspek (1) tampilan antarmuka, (2) navigasi, (3) informasi tambahan media, (4) pembelajaran, serta (5) pertimbangan sikap.

Selain mempertimbangkan kelayakan ahli bidang materi dan media pembelajaran, sudah semestinya dilakukan uji kelayakan dari sisi calon pengguna media itu sendiri. Reddi et al. (2003, p. 57) telah merancang kisi-kisi penilaian multimedia pembelajaran melalui empat aspek, yaitu (1) efektivitas pembelajaran, (2) nilai hiburan, (3) kenyamanan penggunaan, dan (4) fitur desain. Aspek-aspek tersebut sesuai untuk kisi-kisi instrumen penilaian dari persepsi pengguna.

Kemajuan teknologi telah melahirkan sumber-sumber belajar baru. Digitalisasi menjadi karakter pembeda sumbersumber tersebut (Dopo \& Ismaniati, 2016, p. 14). Secara potensial, game digital Android lebih praktis, menarik, dan berkonten ringkas sehingga dapat memperluas kesempatan belajar penggunanya. Selain itu, game digital Android merupakan sajian produk multimedia karena terdapat elemen teks, gambar, suara, animasi, dan interaktivitas. Game dapat digunakan untuk mengeksplorasi dan membangun konsep disertai hubungan konteks yang otentik (Woo, 2014, p. 293). Karakteristik produk tersebut sesuai dengan kebutuhan pembelajaran materi Domain TP yang cenderung bersifat konseptual. Beberapa penelitian relevan juga telah menunjukkan manfaat game digital/komputer pada berbagai tujuan, metode, dan materi pembelajaran.

Agar pengajaran konvensional yang sudah berjalan dapat terbantu, maka penelitian dan pengembangan alternatif media belajar baru dapat dijadikan rasional utama. Salah satu upaya yang dapat ditawarkan adalah menambahkan game berbasis Android sebagai variasi media belajar pen- dukung materi Domain TP. Media belajar tersebut ditambahkan agar mahasiswa mampu menguasai materi yang luas dengan lebih cepat.

Berdasarkan latar belakang masalah yang diuraikan tersebut, dilaksanakanlah penelitian dan pengembangan game Android Domain TP untuk mahasiswa prodi TP FIP UNY. Tujuan dari penelitian ini adalah menghasilkan produk game berbasis Android tentang materi Domain $\mathrm{TP}$, yang layak dan berdaya guna sebagai alternatif media belajar mahasiswa prodi TP FIP UNY.

\section{Metode}

Penelitian ini merupakan penelitian pengembangan atau dikenal dengan istilah (Research \& Development). Game Android Domain TP dikembangkan melalui tahapan (1) analisis, (2) perencanaan, (3) perancangan, (3) pengembangan, dan (4) evaluasi. Setiap tahapan tersebut terdapat beberapa langkah kerja yang diadaptasi dan diseleksi dari model pengembangan multimedia pembelajaran Alessi \& Trollip (2001, p. 410), model tersebut relevan karena mencakup segala jenis pengembangan multimedia pembelajaran berbasis komputer. Model terdiri dari tiga atribut dan tiga fase. Tiga atribut adalah (1) standar (2) evaluasi berkelanjutan, dan (3) pengelolaan proyek. Tiga fase dalam model adalah (1) perencanaan (planning), (2) perancangan (design), dan (3) pengembangan (development).

Penelitian dan pengembangan game Android Domain TP dilaksanakan selama 8 bulan dari Desember 2015 - Agustus 2016. Penelitian mengambil seting tempat di FIP UNY, Sleman, Yogyakarta. Responden utama penelitian ini adalah mahasiswa prodi TP tahun pertama (angkatan 2015) FIP UNY. Responden penelitian secara menyeluruh antara lain: (1) analisis kebutuhan (studi pendahuluan) dengan 1 narasumber dosen pengampu dan 2 mahasiswa (koordinator) prodi; (2) survei gaya belajar VAK seluruh (60) mahasiswa prodi TP FIP UNY tahun pertama; (3) Pengujian formatif alfa dibantu 2 ahli media dan 2 ahli materi; (4) 
Pengujian formatif beta dibantu oleh 7 mahasiswa prodi TP FIP UNY tahun pertama; (5) Evaluasi sumatif uji eksperimen dibantu oleh 30 mahasiswa prodi TP FIP UNY tahun pertama.

Prosedur penelitian pengembangan game Android Domain TP meliputi (1) Studi pendahuluan: Analisis kebutuhan, wawancara, studi pustaka; (2) Perencanaan: Menentukan ruang lingkup, identifikasi pengguna, seleksi dan koleksi referensi, brainstorming; (3) Perancangan: Membuat konsep kerja, membuat storyboard, membuat flowchart, merancang antarmuka, seleksi perangkat pendukung, evaluasi dan revisi desain; (4) Pengembangan: Menyiapkan konten dan multimedia, materi pendukung, integrasi konten dan multimedia, implementasi desain; (5) Evaluasi: Validasi ahli (formatif alfa), revisi awal, validasi pengguna (formatif beta), revisi akhir, pengujian eksperimen (sumatif); (6) Produk final: Implementasi dan publikasi.

Prosedur pengujian/evaluasi produk game Android Domain TP dilalui dengan beberapa proses, baik secara formatif maupun sumatif. Evaluasi formatif (alfa \& beta) terdiri dari uji kelayakan ahli (materi \& media) dan kelompok pengguna terbatas. Dalam rangkaian evaluasi formatif ini dilaksanakan revisi awal untuk uji alfa dan revisi akhir untuk uji beta. Sedangkan evaluasi sumatif terdiri dari uji daya guna melalui rangkaian pengujian eksperimen. Sehingga game Android tersebut dapat dinyatakan sebagai produk $R \mathcal{E} D$ yang tidak hanya teruji secara teoritis, namun juga secara empiris.

Data yang diperoleh dalam penelitian ini berbentuk deskriptif, kualitatif, dan kuantitatif. Data deskriptif diperoleh dari wawancara pada analisis kebutuhan. Data kualitatif didapat dari komentar dan saran perbaikan pada uji alfa. Data kuantitatif diperoleh dari angket gaya belajar, angket uji alfa, angket uji beta, dan soal tes pemahaman materi.

Sebelum pengambilan data, validasi instrumen dilaksanakan melalui expert judgement oleh ahli instrumen yang me- miliki keahlian bidang media dan materi terkait. Ahli instrumen menilai aspek konstruksi (validitas konstruk) dan aspek isi (validitas konten) dari semua instrumen yang dibuat. Kemudian, validasi instrumen soal tes pemahaman materi juga melibatkan dosen pengampu materi terkait.

Teknik pengumpulan data yang digunakan di antaranya wawancara, survei gaya belajar, validasi materi, validasi media, validasi tester dan tes pemahaman materi. Instrumen yang dipakai berbentuk kuesioner/angket tertutup, pedoman wawancara tak terstruktur, dan soal tes pemahaman materi. Instrumen secara lengkap terdiri dari (1) angket gaya belajar VAK, (2) angket kelayakan game Android Domain TP ahli media, (3) angket kelayakan game Android Domain TP ahli materi, (4) angket kelayakan game Android Domain TP tester, (5) pedoman wawancara analisis kebutuhan dosen pengampu, (6) pedoman wawancara analisis kebutuhan mahasiswa prodi TP, (7) soal pretes pemahaman materi Domain TP, (8) soal postes pemahaman materi Domain TP. Kisi-kisi soal tes diambil dari $1 \mathrm{KD}$ dengan 17 indikator.

Data yang diperoleh dari wawancara terkait studi pendahuluan dijadikan sebagai dasar rasional kebutuhan pembelajaran materi Domain TP, pengembangan produk game Android, dan pelaksanaan penelititan.

Untuk teknik analisis data angket gaya belajar VAK, setiap butir soal merupakan representasi jenis aktivitas modalitas visual, auditoris, atau kinestetik (Duckett \& Tatarkowski, 2005, p. 14). Data dari angket dihitung dengan menjumlah skor total dari setiap butir skor yang didapatkan. Sehingga secara keseluruhan dapat diketahui gaya belajar mana yang lebih tinggi. Keterangan mengenai soal dan jenis modalitas dapat dilihat pada Tabel 1.

Untuk teknik analisis data uji kelayakan ahli media, ahli materi, dan tester. Penilai tiap-tiap ahli berjumlah 2 responden $(n=2)$, sedangkan tester 7 responden $(n=7)$. Hasil data dianalisis dari skala Likert 5 poin. Data dianalisis dengan menjumlah- 
kan seluruh skor item dan dicari reratanya. Perhitungan dilaksanakan untuk setiap item, aspek, dan instrumen secara keseluruhan. Rumus konversi nilai ke deskriptif kualitatif dapat disederhanakan seperti pada Tabel 2. Hasil validasi dikumpulkan untuk mengetahui kelayakan dan merevisi produk. Game Android Domain TP yang dikembangkan dapat dikatakan layak dari segi kualitas materi, media, dan calon pengguna (tester) apabila hasil telah memenuhi kriteria kelayakan minimal.

Tabel 1. Perhitungan Angket Gaya Belajar VAK

\begin{tabular}{|c|c|c|c|c|c|}
\hline Visual & Skor & Auditoris & Skor & Kinestetik & Skor \\
\hline Soal no 3 & & Soal no 1 & & Soal no 2 & \\
\hline Soal no 5 & & Soal no 4 & & Soal no 6 & \\
\hline Soal no 8 & & Soal no 10 & & Soal no7 & \\
\hline Soal no 9 & & Soal no 14 & & Soal no 11 & \\
\hline Soal no 13 & & Soal no 17 & & Soal no 12 & \\
\hline Soal no 16 & & Soal no 18 & & Soal no 15 & \\
\hline Total & & Total & & Total & \\
\hline
\end{tabular}

Tabel 2. Kriteria Penilaian Analisis Data

\begin{tabular}{ccc}
\hline Rumus & Rerata & Kategori \\
\hline $\mathrm{X}>\bar{X} \mathrm{i}+1,8 \times \mathrm{sbi}$ & $>4,2$ & Sangat baik \\
$\bar{X} \mathrm{i}+0,6 \times \mathrm{sbi}<\mathrm{X} \leq \bar{X} \mathrm{i}+1,8 \times \mathrm{sbi}$ & $>3,4-4,2$ & Baik \\
$\bar{X} \mathrm{i}-0,6 \times \mathrm{sbi}<\mathrm{X} \leq \bar{X} \mathrm{i}+0,6 \times \mathrm{sbi}$ & $>2,6-3,4$ & Cukup \\
$\bar{X} \mathrm{i}-1,8 \times \mathrm{sbi}<\mathrm{X} \leq \bar{X} \mathrm{i}-0,6 \times \mathrm{sbi}$ & $>1,8-2,6$ & Kurang \\
$\mathrm{X}>\bar{X} \mathrm{i}-1,8 \times \mathrm{sbi}$ & $\leq 1,8$ & Amat kurang \\
\hline
\end{tabular}

\section{Keterangan:}

$\bar{X} \mathrm{I} \quad=1 / 2($ skor maks ideal + skor min ideal)

Sbi $=1 / 6$ (skor maks ideal - skor min ideal)

$\mathrm{X}=$ Skor aktual/empiris

Terakhir, teknik analisis data uji daya guna. Populasi mahasiswa prodi TP FIP UNY angkatan 2015 dibagi menjadi dua kelompok dengan jumlah seimbang, kelompok pengguna game Android Domain TP (eksperimen) dan kelompok pengguna modul digital (kontrol). Pada langkah pertama, untuk menyamakan titik awal pemahaman responden diberikan pretes pemahaman materi. Pada langkah kedua, responden diberikan kesempatan belajar menggunakan media belajar sesuai kelompoknya. Pada langkah ketiga, responden diberikan postes pemahaman materi. Setelah seluruh rangkaian pengujian selesai, dilakukan perhitungan untuk membandingkan hasil-hasil nilai yang didapatkan.

Pertama, membandingkan hasil nilai pretes dan postes masing-masing kelompok menggunakan uji banding berpasangan. Kemudian diketahui selisih peningkatan nilai setiap kelompok antara sebelum dan sesudah belajar menggunakan medianya masing-masing. Kedua, mencari selisih nilai gain dari hasil pretes dan postes setiap responden, setelah diketahui segera dilakukan uji banding bebas antara nilai gain kedua kelompok uji. Seluruh perhitungan statistik tersebut dikerjakan melalui aplikasi IBM SPSS (Statistical Package for the Social Sciences). Pengujian ini memiliki ketentuan sebagai berikut:

1) Hipotesis yang diajukan:

$\mathrm{HO}=$ tidak terdapat perbedaan antara hasil belajar pengguna game Android Domain TP dengan pengguna modul digital Domain TP

$\mathrm{Ha}=$ terdapat perbedaan antara hasil belajar pengguna game Android Domain TP dengan pengguna modul digital Domain TP

2) Taraf signifikansi:

$a=0,05$ atau $5 \%$

3) Dasar pengambilan keputusan:

Jika Sig >0,05, H0 diterima dan Ha ditolak

Jika Sig <0,05, H0 ditolak dan Ha diterima

Produk game Android Domain TP dapat dinyatakan bermanfaat dari segi daya guna apabila rerata hasil tes pemahaman kelompok eksperimen memperoleh selisih peningkatan yang lebih tinggi dan berbeda secara signifikan.

\section{Hasil dan Pembahasan}

Hasil pada tahap studi pendahuluan telah dituliskan dalam bab pendahuluan, dari studi tersebut diperoleh beberapa poin penting terkait identifikasi masalah dan kebutuhan yang dapat diberikan solusi. 
Hasil pengembangan produk awal adalah media pembelajaran game Android Domain TP versi 1.0 dengan nama "Rumah Alumni Teknologi Pendidikan (Definisi 1994)". Produk yang dikembangkan dalam penelitian ini merupakan program berbentuk game edukasi (edutainment) yang mengadaptasi nuansa role playing games (RPG).

\section{Hasil Perencanaan}

Hasil perencanaan meliputi referensi berupa panduan teknis, bahan ajar, situs internet, perangkat lunak, serta tenaga ahli. Sumber-sumber referensi tersebut meliputi (1) sumber materi Domain TP, (2) sumber tentang pembuatan game Android (Unity 3D), (3) sumber aset-aset game (grafis dan suara, berlisensi distribusi bebas bersyarat, agar dapat diambil dan dimodifikasi sesuai kebutuhan). Brainstorming telah menghasilkan gagasan-gagasan baru terkait penelitian dan pengembangan lebih lanjut, seperti bentuk media, rancangan instruksional, kemasan materi, serta informasi terkait sumber.

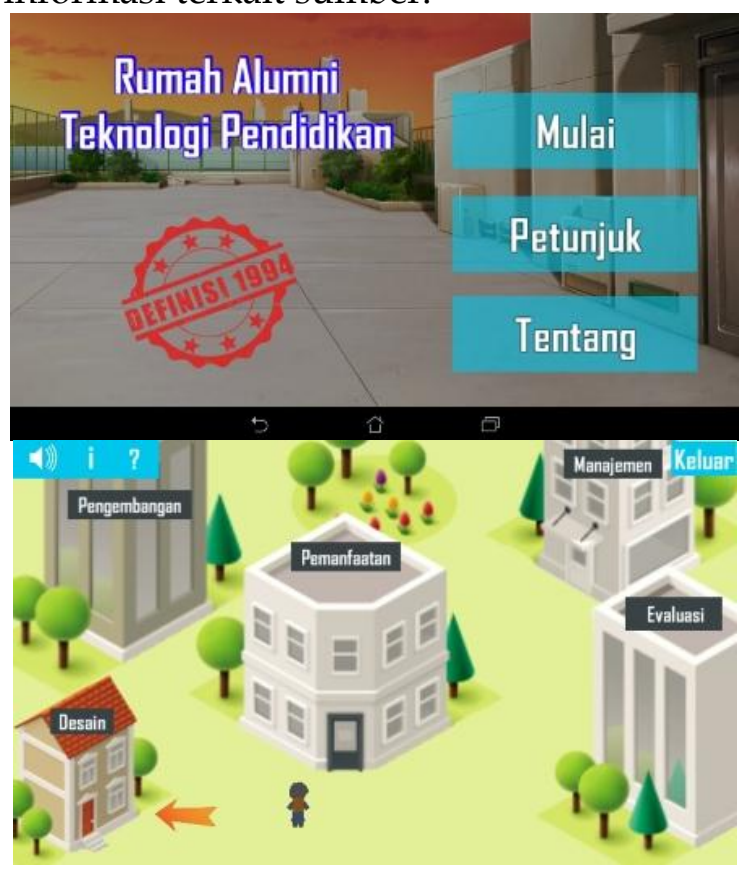

Gambar 1. Menu Utama Game Android Domain TP

Produk awal juga terbuat dari hasil identifikasi gaya belajar VAK pengguna. Hasil survei menunjukkan bahwa mayo- ritas mahasiswa lebih dominan ke modalitas visual. Lebih lengkap hasil pengolahan data disajikan pada Gambar 2.

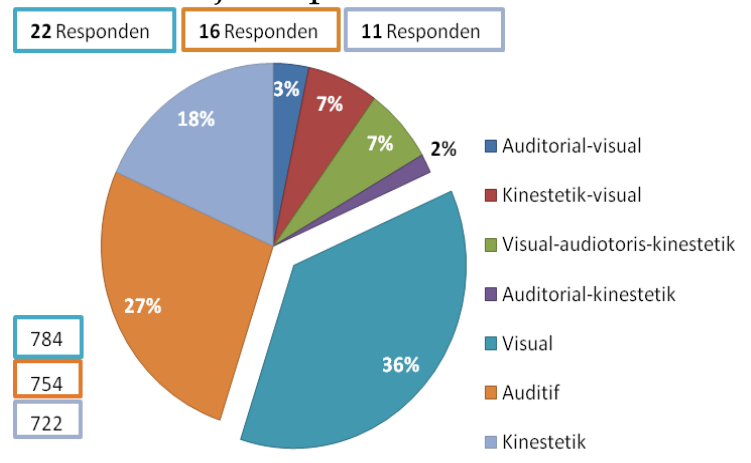

Gambar 2. Grafik Gaya Belajar Mahasiswa Prodi TP 2015

Hasil menunjukkan total skor item visual adalah yang tertinggi (784), diikuti dengan kinestetik (754) dan auditorial (722). Jumlah mahasiswa menurut dominasi gaya belajarnya adalah 22 visual, 16 kinestetik, dan 11 auditorial. Selain itu, terdapat pula mahasiswa yang mendapatkan skor dominasi campuran (4 kinestetik-visual, 2 auditorial-visual, 1 auditorial-kinestetik, dan 4 visual-auditorial-kinestetik). Sehingga dominasi gaya belajar visual terlihat jelas dari skor tertinggi (784), jumlah individu terbanyak (22), dan persentase (36\%).

Pada implikasinya, desain elemen media lebih ditekankan pada penyampaian gaya belajar visual. Aplikasi game telah dikembangkan dengan konten visual yang terdiri dari teks-teks pendek (detil dan spesifik), output teks terorganisir, susunan teks ilustrasi wawancara visual, memuat konsep pokok ilustratif, tanpa narasi suara, serta diberi efek suara seperlunya.

\section{Hasil Perancangan}

Hasil yang didapatkan dalam tahap perancangan di antaranya seperti outline program media, storyboard game, flowchart aplikasi, tampilan antarmuka, adaptasi sumber referensi, serta desain yang ideal melalui evaluasi dan revisi perancangan. Flowchart aplikasi berasal dari rancangan diagram alur, perpindahan konten, dan saluran internal game yang disesuaikan de- 
ngan prosedur aktivitas pengguna. Bentuk flowchart tersaji pada Gambar 3.

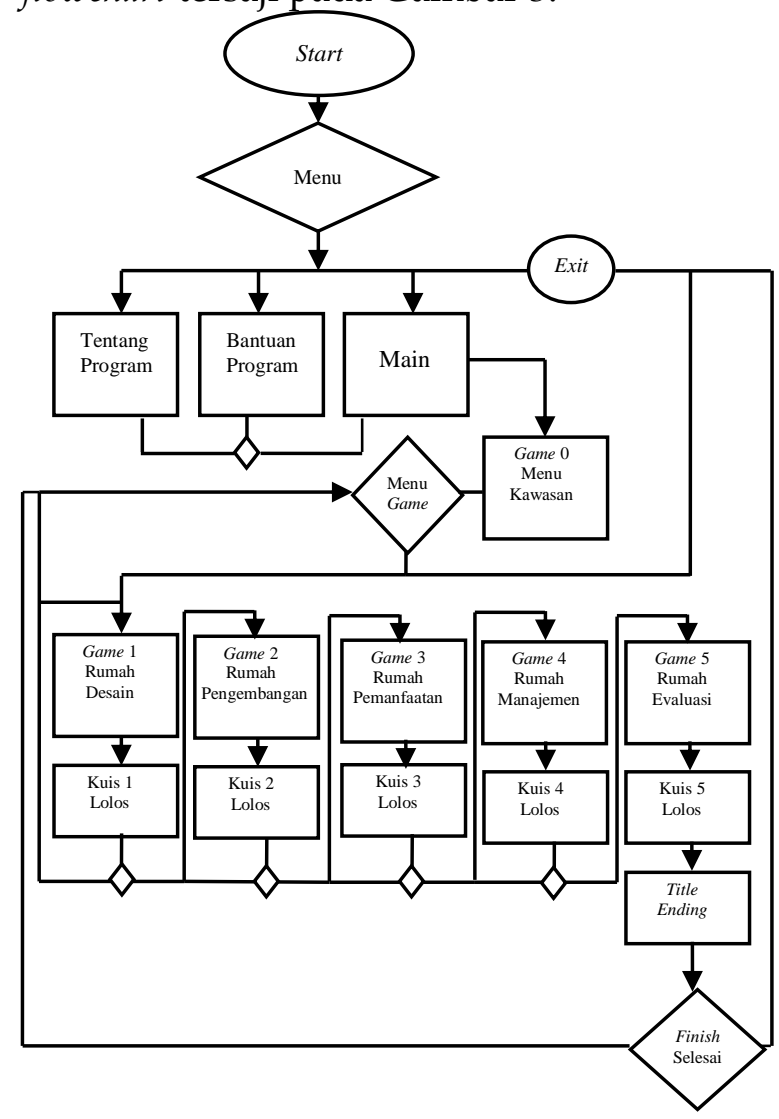

Gambar 3. Flowchart Aplikasi Game Android Domain TP

Hasil Pengembangan

Untuk hasil dalam tahap pengembangan, konten materi dan elemen multimedia telah selesai dipersiapkan. Konten materi yang terbentuk berupa naskah dia$\log$, penyampaian materi merupakan informasi visual bernuansa wawancara. Transfer tersebut menyesuaikan nuansa game yang dipilih (RPG). Konten dibuat berurutan sesuai pembahasan materi yang ada. Elemen multimedia game berupa gambar, teks, dan audio sebagai aset juga selesai disiapkan. Aset tersebut menjadi kemasan, pengiring, dan penjelas untuk penyampaian materi dalam media.

Konten pendukung seperti intro, tujuan pembelajaran, identitas program, peta program, kuis game telah terkumpul. Rancang bangun projek game Android Domain TP dalam Unity 3D telah terbangun. Selanjutnya dilakukan penyesuaian antara desain pembelajaran dengan desain aplikasi. Produk game Android Domain TP versi 1.0 telah selesai dibangun.

Hasil Pengujian Produk

Setelah game Android Domain TP versi 1.0 selesai dikembangkan, maka dilakukan uji coba produk melalui uji alfa dan uji beta. Hasil digunakan sebagai penentu standar dan acuan revisi. Berikut penjelasan hasil uji formatif alfa yang lebih rinci.

Validasi materi dilaksanakan oleh dua ahli materi bidang Teknologi Pendidikan. Hasil disajikan pada Tabel 3.

Tabel 3. Distribusi Frekuensi Validasi Materi

\begin{tabular}{|c|c|c|c|c|}
\hline \multirow[b]{2}{*}{ No } & \multirow[b]{2}{*}{ Aspek Penilaian } & \multicolumn{2}{|c|}{ Hasil Penilaian } & \multirow[b]{2}{*}{ Rerata } \\
\hline & & $\begin{array}{c}\text { Ahli } \\
\text { materi } 1\end{array}$ & $\begin{array}{c}\text { Ahli } \\
\text { Materi } 2\end{array}$ & \\
\hline 1 & Subjek Materi & 3,8 & 3,9 & 3,85 \\
\hline 2 & Materi pendukung & 4,75 & 5 & 4,90 \\
\hline 3 & Desain Pembelajaran & 3,77 & 4 & 3,88 \\
\hline \multicolumn{4}{|c|}{ Rerata Keseluruhan } & 4,21 \\
\hline \multicolumn{4}{|c|}{ Kategori } & $\begin{array}{c}\text { Sangat } \\
\text { Baik }\end{array}$ \\
\hline
\end{tabular}

Hasil tersebut menyatakan bahwa materi dalam game Android Domain TP versi 1.0 telah layak, ahli materi 1 menyatakan dapat digunakan dengan sedikit revisi disertai beberapa komentar dan ahli materi 2 menyatakan dapat digunakan dengan banyak revisi disertai beberapa komentar. Rata-rata nilai validasi yang didapatkan adalah 4,21, sesuai acuan konversi deskripsi kualitatif hasil tersebut masuk dalam kategori "Sangat Baik" ( $X>\mathbf{4}, 2)$.

Menurut data tersebut, aspek materi pendukung memiliki rata-rata penilaian tertinggi yaitu 4,9 sehingga masuk kategori "Sangat Baik". Aspek subjek materi dan desain pembelajaran mendapatkan ratarata yang hampir mencapai 3,9, sehingga masuk kategori "Baik". Pemberian skor kedua ahli materi pada setiap item indikator dari keseluruhan aspek hanya berbeda 1 poin. Skor terendah yang didapatkan pada seluruh item adalah 3, sehingga menurut kedua ahli materi kualitas setiap indikator sudah memenuhi kriteria "Cukup". Setelah 
melewati tahap penilaian ini disimpulkan bahwa konten materi game Android Domain TP dinyatakan sangat baik $(\mathbf{4 , 2 1})$, sehingga layak untuk digunakan uji coba lanjut dengan menambahkan revisi.

Selanjutnya, validasi media dilaksanakan oleh dua ahli bidang multimedia pembelajaran yang juga memiliki pengetahuan tentang Teknologi Pendidikan. Hasil validasi disajikan pada Tabel 4 .

Tabel 4. Distribusi Frekuensi Validasi Media

\begin{tabular}{|c|c|c|c|c|}
\hline \multirow[b]{2}{*}{ No } & \multirow[b]{2}{*}{ Aspek Penilaian } & \multicolumn{2}{|c|}{ Hasil Penilaian } & \multirow[b]{2}{*}{ Rerata } \\
\hline & & $\begin{array}{c}\text { Ahli } \\
\text { Media } 1\end{array}$ & $\begin{array}{c}\text { Ahli } \\
\text { Media } 2\end{array}$ & \\
\hline 1 & Tampilan antarmuka & 4,14 & 3,75 & 3,95 \\
\hline 2 & Navigasi & 4,2 & 3,8 & 4 \\
\hline 3 & Informasi pendukung & 3,88 & 3,37 & 3,63 \\
\hline 4 & Desain pembelajaran & 4,09 & 3,73 & 3,91 \\
\hline \multirow{2}{*}{\multicolumn{4}{|c|}{$\begin{array}{c}\text { Rerata Keseluruhan } \\
\text { Kategori }\end{array}$}} & 3,87 \\
\hline & & & & Baik \\
\hline
\end{tabular}

Hasil tersebut menyatakan bahwa media pembelajaran game Android Domain TP versi 1.0 telah layak, kedua ahli media menyatakan produk tersebut dapat digunakan dengan sedikit revisi disertai beberapa komentar. Rata-rata nilai validasi yang didapatkan adalah 3,87, sesuai acuan konversi deskripsi kualitatif hasil tersebut masuk kategori "Baik" ( $X \geq 3,4)$.

Menurut data tersebut, aspek navigasi mendapatkan rerata penilaian paling tinggi (4) dan masuk kategori "Baik". Aspek tampilan antarmuka mendapatkan rerata nilai 3,95 sehingga masuk dalam kategori "Baik". Aspek informasi pendukung mendapatkan rerata nilai terendah dengan 3,63, namun masih dalam kategori "Baik". Pada aspek ini didapatkan selisih rerata nilai paling besar $(\mathbf{0}, 59)$, inilah penyebab rerata aspek menjadi lebih rendah dari aspek lainnya. Terakhir, pada aspek desain pembelajaran didapatkan rerata nilai 3,91 sehingga sudah dapat dikatakan "Baik". Setelah melewati tahap penilaian ini disimpulkan bahwa media game Android Domain TP dinyatakan baik $(3,87)$, sehingga layak untuk digunakan uji coba lanjut disertai revisi.
Revisi pertama materi dan media dilakukan untuk memperbaiki konten dan desain produk. Revisi dilaksanakan sesuai dengan penilaian, komentar, dan saran perbaikan para ahli. Seluruh perbaikan telah selesai dilakukan sebelum dilanjutkan ke pengujian formatif beta.

Pengujian beta dilaksanakan dengan mengujicobakan produk game Android Domain TP versi 2.0 (versi baru setelah alfa). Uji beta validasi tester dilaksanakan oleh 7 mahasiswa prodi TP FIP UNY tahun pertama. Hasil disajikan pada Tabel 5.

Tabel 5. Distribusi Frekuensi Uji Beta

\begin{tabular}{|c|c|c|c|c|c|c|c|c|}
\hline \multirow{2}{*}{$\begin{array}{c}\text { Aspek } \\
\text { Penilaian }\end{array}$} & \multicolumn{7}{|c|}{ Tester } & \multirow{2}{*}{$\begin{array}{l}\text { Rerata } \\
\text { aspek }\end{array}$} \\
\hline & 1 & 2 & 3 & 4 & 5 & 6 & 7 & \\
\hline $\begin{array}{l}\text { Efektivitas } \\
\text { pembelajaran }\end{array}$ & 3,8 & 3,2 & 3,8 & 3,8 & 3,4 & 3 & 3,2 & 3,46 \\
\hline Nilai hiburan & 3,67 & 4 & 4 & 5 & 3,67 & 3,33 & 3,67 & 3,90 \\
\hline $\begin{array}{l}\text { Kenyamanan } \\
\text { penggunaan }\end{array}$ & 4 & 4 & 4 & 4 & 3,33 & 3,67 & 4,67 & 3, \\
\hline \multirow[t]{3}{*}{ Fitur desain } & 4 & 4 & 3,75 & 4,75 & 3,25 & 4 & 3,5 & 3,89 \\
\hline & & & & & & \multicolumn{2}{|c|}{ Rerata } & 3,80 \\
\hline & & & & & & \multicolumn{2}{|c|}{ Keterangan } & Baik \\
\hline
\end{tabular}

Berdasarkan hasil tersebut, game Android Domain TP versi 2.0 dikatakan layak untuk mendukung pembelajaran oleh calon pengguna dengan menambahkan perbaikan. Rata-rata nilai yang didapatkan 3,80, sesuai acuan konversi deskripsi kualitatif hasil tersebut masuk dalam kategori "Baik" ( $X \geq 3,4)$.

Menurut data tersebut, aspek kenyamanan penggunaan memperoleh ratarata penilaian paling tinggi $(3,95)$ dan masuk kategori "Baik". Aspek nilai hiburan memperoleh skor tertinggi kedua dengan rata-rata 3,90 dan masuk kategori "Baik". Aspek fitur desain memperoleh rata-rata 3,89 sehingga masuk kategori "Baik". Pada item indikator kualitas desain grafis didapatkan skor rerata item tertinggi dengan 4,57. Aspek terakhir adalah efektivitas pembelajaran, didapatkan nilai rata-rata terendah 3,46 tetapi masih dalam kategori "Baik".

Secara keseluruhan, item indikator kesesuaian tujuan belajar dan kelengkapan materi mendapatkan rata-rata item teren- 
dah yaitu 3,29. Maka dua indikator tersebut dijadikan prioritas utama pada revisi akhir. Selanjutnya, item indikator kelengkapan informasi pendukung dan kualitas elemen audio dijadikan prioritas kedua, rata-rata item tersebut $\mathbf{3}, \mathbf{4 3}$. Tiga dari empat item indikator ini berada pada aspek efektivitas pembelajaran, sehingga perhatian utama revisi tahap akhir adalah pada aspek tersebut. Setelah melewati pengujian beta, disimpulkan bahwa game Android Domain TP versi 2.0 dinyatakan baik $(3,80)$, sehingga layak diuji daya gunanya disertai revisi terlebih dahulu.

Sesuai dengan langkah-langkah pengujian yang ditentukan, revisi produk pada penelitian ini dilakukan 2 kali, di samping secara berkelanjutan. Revisi kedua dilakukan untuk memperbaiki produk sesuai penilaian calon pengguna. Perbaikan dilaksanakan dengan mempertimbangkan acuan nilai terendah indikator penilaian. Seluruh perbaikan revisi akhir telah selesai dilakukan sebelum digunakan pada pengujian daya guna (sumatif).

Terakhir, dihasilkan produk final untuk uji daya guna (revisi akhir dari uji beta), yaitu game Android Domain TP versi 3.0. Produk final dijadikan media belajar yang digunakan oleh kelompok responden eksperimen. Responden adalah populasi mahasiswa TP angkatan 2015 dengan jumlah 30. Rencana awal pengujian ini dilaksanakan dengan kedua kelas angkatan 2015, namun ketika pelaksanaan salah satu kelas tidak dapat ikut membantu dikarenakan mendapat tugas akhir kuliah yang mendesak waktunya.

Sebelum melakukan uji banding antara hasil nilai pretes dan postes setiap kelompok, harus diketahui dulu distribusi data tersebut dengan uji normalitas. Hasil uji normalitas kelompok kontrol tersaji pada Tabel 6.

Karena jumlah responden hanya 30, hasil uji normalitas yang dipakai adalah Shapiro-Wilk. Berdasarkan hasil tersebut, diketahui nilai sig kelompok kontrol 0,09 pada pretes dan $\mathbf{0 , 1 1 7}$ pada postes, dimana sig $>0,05$. Sehingga hasil nilai kelompok kontrol berdistribusi normal, untuk selanjutnya uji banding berpasangan dihitung dengan paired $t$ test. Hasil pengujian disajikan pada Tabel 7.

Tabel 6. Uji Normalitas Kelompok Kontrol

\begin{tabular}{lcccccc}
\hline \multicolumn{7}{c}{ Tests of Normality } \\
& Kolmogorov-Smirnova & \multicolumn{3}{c}{ Shapiro-Wilk } \\
& Static & df & Sig. & Statistic & df & Sig. \\
\hline Pretes &, 220 & 15 &, 049 &, 899 & 15 &, $\mathbf{0 9 0}$ \\
Postes &, 166 & 15 &, $200^{*}$ &, 906 & 15 &, $\mathbf{1 1 7}$ \\
\hline
\end{tabular}

Tabel 7. Hasil Uji Banding Pretes dan Postes Kelompok Kontrol

\begin{tabular}{|c|c|c|c|c|c|c|c|}
\hline & & & Paire & Sample & Test & & \\
\hline & & & ired D & ferences & & & \\
\hline & Mean & $\begin{array}{l}\text { Std. } \\
\text { Dev }\end{array}$ & $\begin{array}{l}\text { Std. } \\
\text { Error }\end{array}$ & $\begin{array}{r}95 \% \text { Co } \\
\text { Interva } \\
\text { Diffe }\end{array}$ & $\begin{array}{l}\text { idence } \\
\text { of the } \\
\text { nce }\end{array}$ & $\mathrm{t} \quad \mathrm{df}$ & $\begin{array}{c}\text { Sig. } \\
\text { 2-tailed }\end{array}$ \\
\hline & & & & Lower & Upper & & \\
\hline $\begin{array}{c}\text { Pretes } \\
- \\
\text { Postes }\end{array}$ & -9000 & 16,9 & 4,37 & $-18,372$ & 372 & 2,0614 & ,059 \\
\hline
\end{tabular}

Berdasarkan hasil tersebut, didapatkan nilai sig pretes dan postes kelompok kontrol sebesar 0,059. Bahwa nilai sig $0,059>0,05$, sehingga ada perbedaan mendekati signifikan yang dialami kelompok kontrol antara sebelum dan sesudah belajar dengan modul digital.

Lebih lanjut, Hasil uji normalitas kelompok eksperimen tersaji pada Tabel 8.

Tabel 8. Uji Normalitas Kelompok Eksperimen

\begin{tabular}{|c|c|c|c|c|c|c|}
\hline \multicolumn{7}{|c|}{ Tests of Normality } \\
\hline & \multicolumn{3}{|c|}{ Kolmogorov-Smirnova } & \multicolumn{3}{|c|}{ Shapiro-Wilk } \\
\hline & Statistic & $\mathrm{df}$ & Sig. & Statistic & $\mathrm{df}$ & Sig. \\
\hline Pretes & 206 & 15 & ,086 & 927 & 15 & ,244 \\
\hline Postes & 182 & 15 & 193 & 924 & 15 & 224 \\
\hline
\end{tabular}

Berdasarkan hasil tersebut, nilai sig kelompok eksperimen 0,244 pada pretes dan 0,224 pada postes, dimana sig $>0,05$. Sehingga hasil nilai kelompok eksperimen berdistribusi normal, untuk selanjutnya uji banding berpasangan dihitung dengan paired $t$ test. Hasil pengujian disajikan pada Tabel 9.

Berdasarkan hasil tersebut, didapatkan nilai sig ( $\alpha$ ) pretes dan postes kelompok eksperimen sebesar $\mathbf{0 , 0 0 0}$. Bahwa nilai 
sig $0,00<0,05$, sehingga ada perbedaan signifikan yang dialami kelompok eksperimen antara sebelum dan sesudah belajar dengan game Android Domain TP. Hasil tersebut menunjukkan bahwa kelompok eksperimen telah mengalami peningkatan nilai yang lebih besar dibandingkan kelompok kontrol.

Tabel 9. Hasil Uji Banding Pretes dan Postes Kelompok Eksperimen

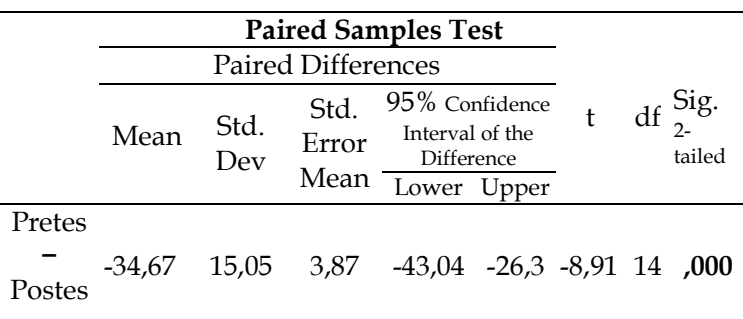

Pada langkah terakhir, dicari nilai gain masing-masing responden setiap kelompok. Setelah didapatkan, dilakukan uji banding bebas antara nilai gain kedua kelompok uji. Sebelum uji banding bebas dilakukan, perlu diketahui distribusi dan kesamaan varian data. Maka dilakukanlah uji normalitas dan homogenitas. Hasil ditampilkan pada Tabel 10 dan Tabel 11.

Tabel 10. Uji Normalitas Nilai Gain Kedua Kelompok

\begin{tabular}{ccccccc}
\hline \multicolumn{7}{c}{ Tests of Normality } \\
Gain & \multicolumn{4}{c}{ Kolmogorov-Smirnova } & \multicolumn{3}{c}{ Shapiro-Wilk } \\
& Statistic & df & Sig. & Statistic & df & Sig. \\
\cline { 2 - 7 } Kontrol &, 169 & 15 &, 200 &, 928 & 15 &, $\mathbf{2 5 5}$ \\
Eksp. &, 113 & 15 &, 200 &, 966 & 15 &, $\mathbf{8 0 1}$ \\
\hline
\end{tabular}

Tabel 11.Uji Homogenitas Nilai Gain Kedua Kelompok

\begin{tabular}{lccc}
\hline \multicolumn{4}{l}{ Test of Homogeneity of Variances } \\
\hline Gain & & & \\
\hline Levene Statistic & df1 & df2 & Sig. \\
\hline, 524 & 1 & 28 &, 475 \\
\hline
\end{tabular}

Berdasarkan hasil uji normalitas, sig (a) dari nilai gain kelompok kontrol 0,255 dan kelompok eksperimen 0,801, dimana sig $>0,05$. Sehingga data berdistribusi normal. Kemudian pada hasil uji homogenitas, sig sebesar $\mathbf{0 , 4 7 5}$, di mana sig $>0,05$, dengan demikian data bersifat homogen. Setelah diketahui distribusi data normal dan bersifat homogen, uji banding bebas yang digunakan adalah independent $t$ test. Hasil uji $t$ bebas disajikan pada Tabel 12 .

Tabel 12. Uji Banding Rerata Gain Kelompok

\begin{tabular}{cccccc}
\hline \multicolumn{5}{c}{ Group Statistics } \\
Kelompok & $\mathrm{N}$ & Mean & $\begin{array}{c}\text { Std. } \\
\text { Deviation }\end{array}$ & $\begin{array}{c}\text { Std. } \\
\text { Error } \\
\text { Mean }\end{array}$ \\
\hline Gain Kontrol & 15 & $\mathbf{9 , 0 0 0 0}$ & 16,92420 & 4,36981 \\
& & & & 15,05545 & 3,88730 \\
\hline
\end{tabular}

Berdasarkan rerata kelompok, diketahui nilai kelompok kontrol sebesar 9 dan kelompok eksperimen sebesar 34,67. Sehingga kelompok eksperimen memiliki rerata peningkatan nilai yang lebih tinggi. Lebih lanjut perbedaan bermakna dapat dilihat pada Tabel 13.

Tabel 13. Uji Banding Nilai Gain Kedua Kelompok

\begin{tabular}{|c|c|c|c|c|c|c|}
\hline \multirow[b]{4}{*}{$\begin{array}{l}\text { Equal } \\
\text { variances } \\
\text { assumed }\end{array}$} & \multicolumn{6}{|c|}{ t-test for Equality of Means } \\
\hline & \multirow[t]{2}{*}{$t$} & \multirow[t]{2}{*}{$\begin{array}{l}\text { Sig. } \\
\text { 2-tailed }\end{array}$} & \multirow[t]{2}{*}{$\begin{array}{l}\text { Mean } \\
\text { Differ. }\end{array}$} & \multirow[t]{2}{*}{$\begin{array}{l}\text { Std. } \\
\text { Error } \\
\text { Differ. }\end{array}$} & \multicolumn{2}{|c|}{$\begin{array}{c}95 \% \text { Confidence } \\
\text { Interval of the } \\
\text { Difference }\end{array}$} \\
\hline & & & & & Lower & Upper \\
\hline & $-4,39 \quad 28$ & ,000 & $-25,667$ & 5,848 & $-37,64$ & $-13,68$ \\
\hline $\begin{array}{l}\text { Equal } \\
\text { variances not }\end{array}$ & $t^{-4,3927,62}$ & ,000 & $-25,667$ & 5,848 & $-37,65$ & $-13,67$ \\
\hline
\end{tabular}

Karena data bersifat homogen, digunakan baris pertama pada kolom sig (2tailed). Diketahui bahwa nilai sig (2-tailed) sebesar 0,000, dimana sig < 0,05. Maka sesuai dasar pengambilan keputusan sebelumnya, dapat dikatakan bahwa H0 ditolak dan Ha diterima. Sehingga terdapat perbedaan hasil belajar signifikan antara kelompok pengguna game Android Domain TP dengan kelompok pengguna modul digital Domain TP. Besarnya perbedaan rerata (mean difference) bernilai negatif $(-25,67)$, maka kelompok kontrol memiliki rerata peningkatan yang lebih rendah. Sehingga, game Android Domain TP sebagai media pembelajaran terbukti memiliki daya guna 
untuk meningkatkan pemahaman tentang materi terkait.

\section{Simpulan dan Saran}

Produk akhir hasil penelitian dan pengembangan adalah game Android Domain TP versi 3.0. Ekstensi format produk adalah file *.apk dan berukuran sekitar 20 $\mathrm{MB}$, setara dengan game-game kausal Android yang beredar di pasaran. Peneliti membatasi level evaluasi hanya pada (1) assesing reaction and attitude (respon dan sikap pebelajar) dan (2) assesing learning (pencapaian hasil belajar). Seluruh hasil penelitian dan pengembangan dapat menyimpulkan beberapa hal.

Pertama, bentuk game Android yang layak sebagai media pembelajaran tambahan untuk materi Domain TP perlu dirancang berdasarkan analisis kebutuhan pembelajaran, merujuk pada capaian pembelajaran, memiliki penekanan format penyajian media, serta sesuai dengan mayoritas gaya belajar calon pengguna. Selain itu bentuk produk juga perlu dirancang dan dikembangkan berdasarkan kajian teori belajar, prinsip game digital, dan penelitian yang relevan. Proses pengembangan produk harus dilaksanakan melalui tahapan yang jelas, memanfaatkan hardware dan software yang handal, mengacu pada implementasi desain (outline, flowchart, storyboard), serta diiringi evaluasi secara berkelanjutan.

Produk game Android Domain TP dapat dikatakan layak sebagai media pembelajaran alternatif berdasarkan kualitas materi, media, dan calon pengguna. Hal tersebut dibuktikan dari hasil penilaian evaluasi formatif (alfa dan beta). Pada uji alfa, ahli materi memberikan rerata penilaian yang masuk pada kategori sangat layak. Sedangkan ahli media memberikan rerata penilaian yang masuk pada kategori layak. Pada uji beta, para mahasiswa yang berperan sebagai tester memberikan rerata penilaian yang masuk pada kategori layak.

Produk game Android Domain TP dikatakan layak sebagai media pembelajaran alternatif berdasarkan manfaat daya guna. Pada evaluasi sumatif melalui rangkai- an uji eksperimen, dibuktikan bahwa rerata penilaian yang didapatkan dari selisih nilai pretes dan postes kedua kelompok uji jauh berbeda. Kelompok pengguna game Android Domain TP (eksperimen) mendapatkan rerata peningkatan yang lebih tinggi. Melalui uji banding nilai gain, diketahui bahwa ada perbedaan yang signifikan antara hasil belajar kedua kelompok uji pada tingkat probabilitas 5\% $(0,00$ sig < 0,05).

Produk hasil penelitian dan pengembangan telah selesai diproduksi dan teruji secara layak dan bermanfaat, diharapkan pemanfaatan teknologi game berbasis Android dapat memberikan kontribusi untuk pembelajaran dan Teknologi Pendidikan secara berkepanjangan.

Pemanfaatan produk game Android Domain TP dihimbau meliputi: (1) Pemanfaatan lebih lanjut pada satuan pembelajaran yang lebih lama dan luas, sehingga dapat diketahui manfaat atau kelemahannya dalam pembelajaran formal; (2) Dosen dan para teknolog pendidikan diharapkan bersedia memakai produk sebagai fasilitas media pembelajaran tambahan bagi para pebelajarnya; (3) Para teknolog pendidikan secara umum diharapkan bersedia mencoba, memanfaatkan, menilai, atau bahkan memperbaharui bentuk dan jumlah pembahasan serta konten materi di dalamnya; (4) Mahasiswa prodi Teknologi Pendidikan secara umum diharapkan bersedia memanfaatkan pada pembelajaran materi terkait. Mengingat tujuan utama pengembangan produk tersebut adalah untuk memfasilitasi pembelajarannya.

Diseminasi game Android Domain TP dapat dilakukan dengan cara berikut: (1) menyebarkan kepada para dosen, mahasiswa, dan praktisi TP di lapangan melalui komunikasi langsung dan komunikasi media; (2) menyebarkan kepada masyarakat melalui seminar, diskusi ilmiah, acara organisasi, atau komunitas pebelajar; (3) memasukan produk ke pasar aplikasi online seperti Playstore dan 9Apps agar dapat diunduh dan dipakai oleh masyarakat luas.

Setelah proses pengembangan, pengujian, dan pembahasan produk akhir 
selesai, ditemui beberapa kekurangan pada game Android Domain TP baik secara instruksional, materi, model media, komponen media, pemanfaatan, dan fungsi yang tentunya masih memerlukan dukungan pengembangan lebih lanjut. Produk saat ini telah terdistribusi di pasar aplikasi Google Play dan dapat diakses melalui laman https://play.google.com/store/apps/deta ils?id=com.uut.rumahlumnitp.

\section{Daftar Pustaka}

Alessi, S. M., \& Trollip, S. P. (2001). Multimedia for learning: methods and development (3rd ed.). Boston: Allyn and Bacon.

Blackman, S. (2013). Beginning 3D game development with Unity 4: All-in-one, multi-platform game development. New York: Apress Media LLC.

Blumberg, F. C., \& Fisch, S. M. (2013). Introduction: digital games as a context for cognitive development, learning, and developmental research. New Directions for Child and Adolescent Development, 2013(139), 1-9. https:// doi.org/10.1002/cad.20026

Clark, R. C., \& Mayer, R. E. (2011). Elearning and the science of instruction: Proven guidelines for consumers and designers of multimedia learning. San Francisco USA: Pfeiffer.

Darmawan, D. (2015). Teknologi pembelajaran. Bandung: Remaja Rosdakarya.

Dopo, F. B., \& Ismaniati, C. (2016). Persepsi guru tentang digital natives, sumber belajar digital dan motivasi memanfaatkan sumber belajar digital. Jurnal Inovasi Teknologi Pendidikan, 3(1), 13-24. https:// doi.org/10.21831/tp.v3i1.828 0

Duckett, I., \& Tatarkowski, M. (2005). Practical strategies for learning and teaching on vocational programmes. London: Learning and Skills
Development Agency (LSDA).

Filsecker, M., \& Kerres, M. (2014).

Engagement as a volitional construct. Simulation E Gaming, 45(4-5), 450-470. https://doi.org/10.1177/10468781145 53569

Finnegan, T. (2013). Unity android game development by example beginner's guide. Birmingham UK: Packt Publishing.

Gunawardhana, L. K. P. D., \& Palaniappan, S. (2015). Psychology of digital games and its effects to its users. Creative Education, 6(16), 1726-1732. https:// doi.org/10.4236/ce.2015.6161 74

Hergenhahn, B. R., \& Olson, M. H. (2012). Theories of learning. (Terjemahan Tribowo B.S.). Jakarta: Kencana Prenada Media.

International Data Corporation. (2016). Smartphone OS market share, 2015 Q1. Retrieved January 2, 2016, from http://www.idc.com/prodserv/smar tphone-os-market-share.jsp.

Joyce, B. R., Weil, M., \& Calhoun, E. (2015). Models of teaching. New Jersey: Pearson Education.

Kementerian Pendayagunaan Aparatur Negara republik Indonesia. Peraturan Menteri Negara Pendayagunaan Aparatur Negara Nomor: PER/2/M.PAN/3/2009 tentang Jabatan Fungsional Pengembang Teknologi Pembelajaran (2009).

Miarso, Y. (2013). Menyemai benih teknologi pendidikan. Jakarta: Kencana Prenada Media.

Muhtadi, A. (2006). Karakteristik gaya belajar mahasiswa ditinjau dari preferensi sensori dan lingkungan. Jurnal TEKNODIKA, 4(7), 1-21.

Reddi, U. V., Saxena, A., Dighe, A., Parhar, M., Mishra, S., Rao, A. S., ... Ramanujam, P. R. (2003). Educational multimedia: A handbook for teacher- 
developers. New Delhi India:

Commonwealth Educational Media

Centre for Asia (CEMCA).

Rusman. (2014). Model-model pembelajaran:

Mengembangkan profesionalisme guru.

Jakarta: Rajagrafindo Persada.

Schunk, D. H. (2012). Learning theories an educational perspektif (teori teori pembelajaran: perspektif pendidikan) (terjemahan Eva Hamdiah dan Rahmat Fajar). Yogyakarta: Pustaka Pelajar.

Seels, B. B., \& Richey, R. C. (1994). Instructional technology: The defination and domains of the field.(Terjemahan Dewi S. Prawiradilaga, Raphael Rahardjo, \& Yusufhadi Miarso). Jakarta: Universitas Negeri Jakarta Pres.

Spector, J. M. (2012). Foundations of educational technology: Integrative approaches and interdisciplinary perspectives. New York USA: Routledge.

Sumpter, J. (2015). Make a 2D arcade game in a weekend: with unity. New York:
Apress Media LLC.

Ulicsak, M., \& Williamson, B. (2011). Computer games and learning: $A$ handbook. London: Futurelab.

Ulicsak, M., \& Wright, M. (2010). Games in education: serious games. Bristol: Futurelab.

Warsita, B. (2013). Perkembangan definisi dan kawasan teknologi pembelajaran serta perannya dalam pemecahan masalah pembelajaran. Jurnal KWANGSAN, 1(2), 72-93.

Widoyoko, S. E. P. (2013). Evaluasi program pembelajaran: panduan praktis bagi pendidik dan calon pendidik. Yogyakarta: Pustaka Pelajar.

Woo, J.-C. (2014). Digital game-based learning supports student motivation, cognitive success, and performance outcomes. Educational Technology $\mathcal{E}$ Society, 17(3), 291-307.

Zechner, M. (2011). Beginning android games. New York: Apress Media LLC. 